\section{Organ Loss and Yield Impacts of 'Valencia' Sweet Orange in Response to Fruit Abscission Agents}

\author{
Luis Pozo and Jacqueline K. Burns ${ }^{1}$ \\ Horticultural Sciences Department, University of Florida, IFAS, Citrus \\ Research and Education Center, 700 Experiment Station Road, Lake \\ Alfred, FL 33850
}

Additional index words. 5-chloro-3-methyl-4-nitro-1H-pyrazole, Citrus sinensis, ethephon, fruit detachment force, leaf abscission, 1-methylcyclopropene, postbloom

\begin{abstract}
To successfully use abscission agents for 'Valencia' sweet orange mechanical harvesting throughout the harvest season, unwanted flower, fruitlet, and leaf drop must be assessed and minimized. Ethephon (400 $\left.\mathrm{mg} \cdot \mathrm{L}^{-1}\right)$, 1-methylcyclopropene (1-MCP; 5 mM), ethephon + 1-MCP, 5-chloro-3-methyl-4-nitro-1 H-pyrazole (CMNP; 200 mg. ${ }^{-1}$ ), and a kinetic adjuvant control $[0.15 \%(\mathrm{v} / \mathrm{v})]$ were applied to 'Valencia' branches at various times from full bloom in Mar. 2006 to the end of full bloom in Mar. 2008. Effects of these treatments on fruit detachment force (FDF) and abscission of developing and mature fruit, flowers, and leaves were recorded. Three separate response periods to abscission agent applications were observed: the first spanned the first 100 days after bloom (DAB) and was characterized by high initial response followed by decreasing sensitivity; the second spanned between 100 and $225 \mathrm{DAB}$ and was characterized by little to no response; and the third spanned from 225 DAB to harvest and was characterized by a gain in sensitivity. Young fruitlets in the first response period were highly sensitive to ethephon but were less sensitive to CMNP or ethephon + 1-MCP. Mature fruit in the third response period were highly sensitive to CMNP and less sensitive to ethephon or ethephon +1 -MCP. The application of ethephon resulted in high leaf abscission and showed no clear sensitivity pattern throughout both cropping years. CMNP or ethephon + 1-MCP application caused minimal leaf abscission. The same abscission agent treatments were applied on whole tree canopies 6 and 28 DAB in Mar. 2007. Application date had no significant effect on the measured parameters. Although ethephon application induced high initial leaf drop, leaf area indices determined 7 months after any compound application were not significantly different. However, subsequent 2008 yield in trees sprayed with ethephon in 2007 was significantly less, whereas 2008 flower number was higher. The results indicate a complex interaction of fruitlet abscission and leaf loss during the first response period contributed to yield reduction and increased flower number in ethephon-treated trees.
\end{abstract}

The use of the abscission agent 5-chloro3-methyl-4-nitro-1H-pyrazole (CMNP) in combination with mechanical harvesting increases mature sweet orange fruit removal without causing phytotoxicity to leaves and young developing fruit through most of the harvesting season (Burns et al., 2005; $\mathrm{Li}$ et al., 2008). Work to register this product for Florida mature citrus fruit abscission is ongoing. In the event that CMNP registration fails or is delayed, other abscission agent options such as ethephon (2-chloro-2ethyl-phosphonic acid), methyl jasmonate, and coronatine (Burns, 2002; Burns et al., 2003; Hartmond et al., 2000) remain as viable candidates. Ethephon is an attractive second choice because it is currently registered for use on several food crops and is relatively inexpensive to apply. Previous work demonstrated that unacceptably high defoliation

Received for publication 8 Sept. 2008. Accepted for publication 23 Oct. 2008.

${ }^{1}$ To whom reprint requests should be addressed; e-mail jkbu@crec.ifas.ufl.edu. associated with ethephon applications, especially at high temperatures (Bukovac et al., 1969; Yuan and Burns, 2004), could be abated during the majority of the harvest season by coapplication of the ethylene binding inhibitor 1-methylcyclopropene (1MCP; Pozo and Burns, 2000; Pozo et al., 2004).

To be fully adopted by the citrus industry, an abscission agent must not impact tree health and yield. The sweet orange cultivar Valencia [Citrus sinensis (L.) Osbeck] is a high-quality citrus juice orange in Florida that usually commands a premium price. 'Valencia' is considered a 13- to 16-month crop in Florida, meaning that mature fruit and flowers and/or fruitlets are usually present at the same time. This poses unique challenges for selective mature fruit loosening at and after bloom when abscission agent applications will be required for mechanical harvesting. During bloom and shortly thereafter, fruitlets are in an active cell division stage (Bain, 1958) and highly responsive to growth regulator applications as a result of rapidly changing hormonal and carbohydrate balan- ces and intersink competition (Guardiola and García-Luis, 2000). At the onset of the cell elongation stage of fruitlet growth, certain growth regulators such as CMNP can be applied at concentrations that loosen mature fruit but not fruitlets, whereas ethephon will cause abscission in both (Burns, 2002). In this case, CMNP can be used to selectively loosen mature fruit without removing fruitlets, provided that machine harvesting is performed at reduced frequency (Burns et al., 2006). Developmental changes in sensitivity to abscise naturally or in response to growth regulator applications in fruit such as citrus have been described (Abeles et al., 1992; Brown, 1997; Guardiola and García-Luis, 2000). Little is known, however, if the loss of young sweet orange 'Valencia' fruitlets resulting from abscission agent application at key times in the cropping cycle translates into significant yield reduction. Such information is critical for timing abscission agent applications to achieve the desired outcome and retain next year's yield.

The objectives of this work were 1) to determine fruit loosening and leaf drop responses to abscission agent applications at various times throughout a 2-year cropping cycle; and 2) to assess the impact of abscission agent applications at two key times during the cell division phase of fruitlet growth on yield the next season.

\section{Materials and Methods}

Plant material. Citrus sinensis L. Osbeck cv. Valencia sweet orange trees, grafted on 'Swingle' rootstock, located at the UF/IFAS Citrus Research and Education Center, Lake Alfred, FL, were used in all trials. Trees were between 20 and 23 years of age and irrigation, pest control, and fertilization were provided according to standard commercial practices.

Compounds and application procedures. Abscission agents used in this work were 1) ethephon [(2-chloroethyl) phosphonic acid (Ethrel, 21.7\% ethephon w/v; Aventis Crop Science USA LP, Research Triangle Park, NC)]; and 2) CMNP (15\% w/w a.i., as provided by AgroSource Inc., Westfield, NJ). 1Methylcyclopropene (AgroFresh, Inc., Philadelphia, PA) as SmartFresh (3.3\% a.i.) was also used. Compounds were dissolved in distilled water that contained the organosilicate adjuvant Kinetic (Setre Chemical Co., Collierville, TN) at $0.15 \%(\mathrm{v} / \mathrm{v})$. Treatments described subsequently were applied either to $1-\mathrm{m}^{3}$ canopy branches (Expt. 1) or entire tree canopies (Expt. 2) using a pressurized, 1-L capacity hand sprayer (Expt. 1) or a 12-L capacity motorized backpack sprayer (Expt. 2). Spray solutions were applied until runoff. Rainfall did not occur within $3 \mathrm{~d}$ after application in all trials reported.

Expt. 1: Branch tests. Branch tests were used to determine the fruit and leaf response to monthly applications of abscission agents and compound combinations. For the 20062007 cropping cycle, applications were begun 
on 16 Mar. 2006 (full bloom) and ended 16 Mar. 2007. For the 2007-2008 cropping cycle, applications were begun on 5 Apr. 2007 (full bloom) and ended on 6 Mar. 2008. A block of 90 uniform trees was used for each cropping cycle. Application treatments were $400 \mathrm{mg} \cdot \mathrm{L}^{-1}$ ethephon, $5 \mathrm{~mm}$ 1-MCP, 400 $\mathrm{mg} \cdot \mathrm{L}^{-1}$ ethephon plus $5 \mathrm{~mm} 1-\mathrm{MCP}, 200$ $\mathrm{mg} \cdot \mathrm{L}^{-1} \mathrm{CMNP}$, and a Kinetic (adjuvant) control. 1-MCP was dissolved in spray mixes immediately before application (Pozo et al., 2004). Treatments were randomly applied to five canopy branches (replications) per spray treatment. Each branch contained between 15 and 200 flowers and/or developing fruit and leaves and/or 15 mature fruit, depending on the time of year. Applications were performed on a biweekly to monthly basis throughout the two cropping periods, each covering from full bloom to at least 340 $\mathrm{d}$ after full bloom (DAB). Immediately before application, flower, fruitlet, leaf, and/ or fruit number were counted. The date of each application was noted, and retained organs were counted 30 and $60 \mathrm{~d}$ after application for leaves and fruit, respectively. Percentage retention of fruit was calculated by dividing the remaining fruit on the branch by the initial number and multiplying by 100. The percentage fruit loss in control branches represented nonabscission agentinduced organ loss. The actual abscission agent-related fruit retention was expressed as percentage control and calculated by dividing the percent retention in each abscission agent treatment by the percent retention of the controls and multiplying by 100 . The percent fruit retention after $60 \mathrm{~d}$ for each abscission agent treatment (as percentage control) was plotted by application date. Leaf abscission was calculated by subtracting the final number of leaves from the initial number, dividing by the initial number, and multiplying by 100 . The percent leaf abscission after $30 \mathrm{~d}$ for each abscission agent treatment (as percentage control) was plotted by application date. Fruit growth was measured in both cropping cycles by measuring the equatorial diameter ( $\mathrm{mm}$ ) of developing fruit at various times after full bloom until fruit maturation using a digital caliper (Mitutoyo Digimatic Caliper, Model CD-6 CS; Mitutoyo America Corp., Aurora, IL). In the 2007-2008 cropping year, fruit detachment force (FDF, kg-force) was measured 6 $\mathrm{d}$ after spray treatments in both mature and developing fruit with a digital force gauge (Force Five; Wagner Instruments, Greenwich, CT). For developing fruit, a holding platform was made for the arm of the gauge to hold the small fruitlets in place for measurements. Final results were expressed as percent of control.

Expt. 2: Whole tree application at 6 and 28 d after full bloom. Abscission agent treatments described in Expt. 1 were applied to whole tree canopies. A total of 30 uniform trees was randomly assigned to each of the five treatments for each application date. Each treatment consisted of six single-tree replicates. Before application, trees were
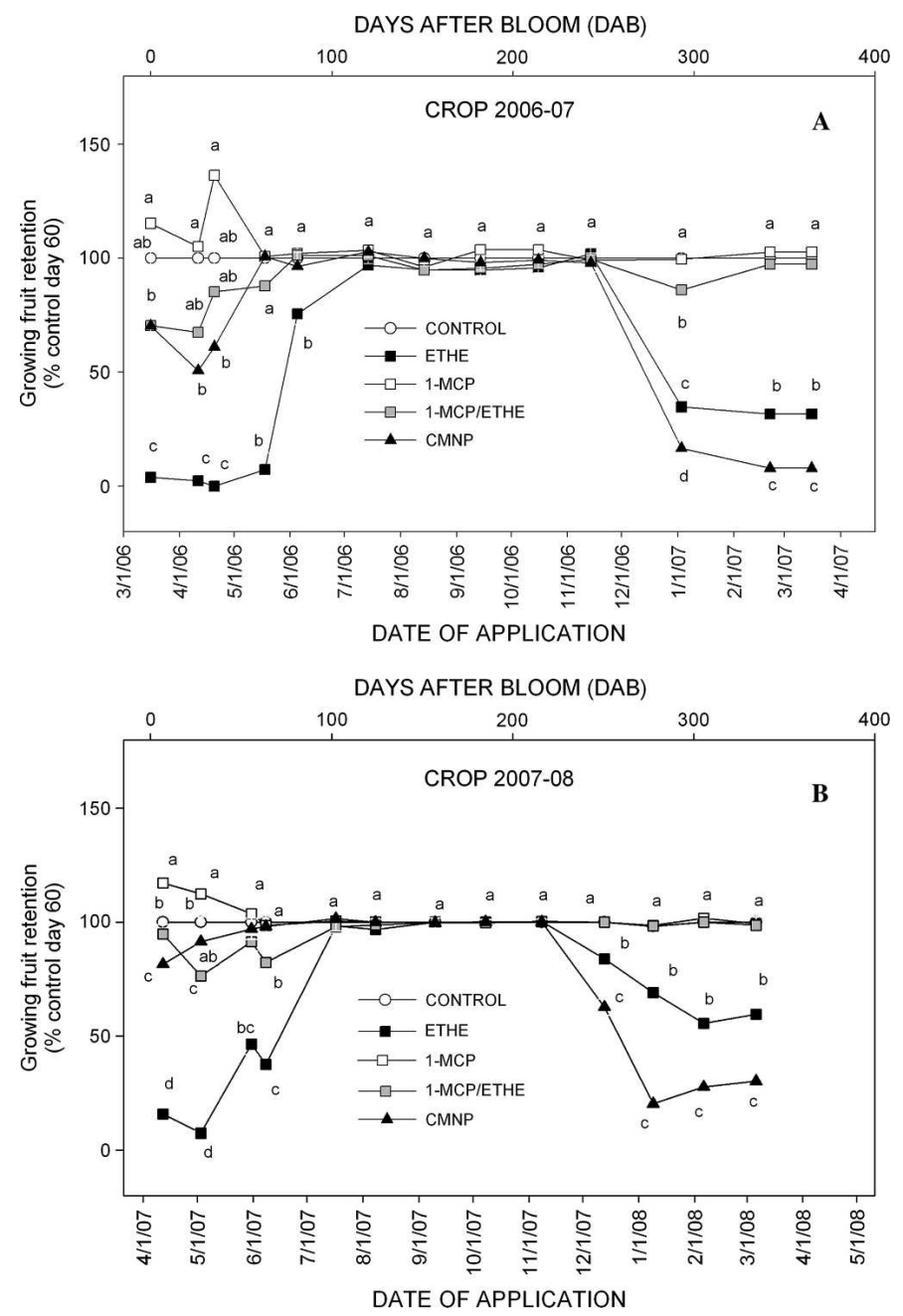

Fig. 1. Retention of 'Valencia' sweet orange growing fruit as percent adjuvant control $60 \mathrm{~d}$ after application. Treatments were applied to runoff as branch sprays in 2 cropping years at the dates indicated: (A) 2006-2007; (B) 2007-2008. Means with the same letter within the same date of application are not significantly different as indicated by Duncan's multiple range test $(P \leq$ 0.05). Ethe = ethephon; 1-MCP = 1-methylcyclopropene; $\mathrm{CMNP}=5$-chloro-3-methyl-4-nitro-1H-pyrazole.

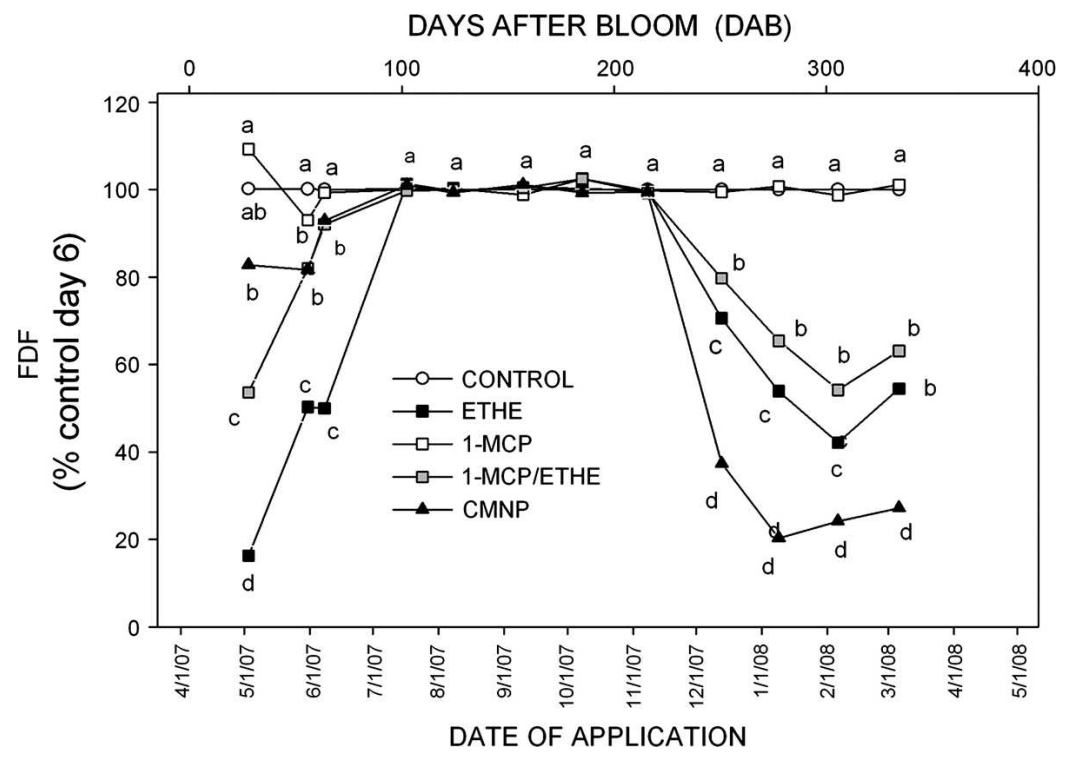

Fig. 2. Fruit detachment force (FDF, percent of control) of 'Valencia' sweet orange fruit $6 \mathrm{~d}$ after application. Treatments were applied to runoff as branch sprays in the 2007-2008 cropping year at the dates indicated. Means with the same letter within the same date of application are not significantly different as indicated by Duncan's multiple range test $(P \leq 0.05)$. Ethe $=$ ethephon; $1-\mathrm{MCP}=1-$ methylcyclopropene; CMNP = 5-chloro-3-methyl-4-nitro-1 $H$-pyrazole. 
harvested in early Apr. 2007 and fruit weighed to obtain the 2007 yield. Abscission agents were applied on two dates corresponding to petal fall (6 DAB, 12 Apr. 2007) and fruit set/postbloom abscission (28 DAB, 4 May 2007). These key dates were selected based on the high rate of natural fruitlet loss beginning at full bloom and ending $\approx 30$ to $40 \mathrm{DAB}$. To measure the recovery of leaf number after application of abscission compounds, leaf area index (LAI) was measured in Nov. 2007 using a $1-\mathrm{m}^{2}$ frame placed at a height of $1.5 \mathrm{~m}$ on both sides of each replicate tree. Leaf number in the frame was used to estimate total number of leaves per tree based on canopy volume measurements. To determine leaf area, a 25-leaf subsample from each replicate tree was taken to the laboratory and average leaf area measured using a portable leaf area meter (LI-3000; LI-COR, Lincoln, NE). LAI was calculated as leaf area divided by the ground surface area under the canopy. Final yield was evaluated by individually harvesting experiment trees in Mar. 2008. Harvested fruit in 2007 and 2008 were weighed and results for 2008 yield expressed as percentage of 2007 yield. To measure flower number per tree, flowers were counted at full bloom (Mar. 2008) using a $1-\mathrm{m}^{2}$ frame and the counts converted into flower number per tree as described previously for total leaf number.

Statistics. Percentage data were transformed to stabilize variance using arcsine transformation in Microsoft Excel functions (Microsoft, Redmond, WA). For the whole tree experiment, data were analyzed as twoway factorial to determine date of application and spray treatment effects on yield. Further analyses were performed using oneway analysis of variance and Duncan's multiple range tests to determine differences between spray treatments within dates. All analyses were performed using the SAS statistical package (SAS Inst. Inc., Cary, NC).

\section{Results}

Expt. 1: Fruit and leaf response on branches sprayed with abscission agents. Three major response periods could be distinguished throughout fruit growth, development, and maturation in both cropping years (Fig. 1). Response Period I, during approximately the first $100 \mathrm{DAB}$, was characterized by high initial response to abscission agent applications followed by decreasing sensitivity. Ethephon induced very high levels of fruitlet drop; less than $5 \%$ of the total fruitlet number was retained when compared with the control. CMNP application resulted in approximately half the initial fruitlet loss. Addition of 1-MCP to the ethephon spray mix greatly reduced ethephon-induced fruitlet drop, but retention remained less than that in controls. 1-MCP treatment alone numerically increased fruitlet retention. Response Period II, covering $\approx 100$ through 225 DAB, was characterized by little or no response of developing fruit to abscission agents at the concentrations applied. Response Period III,
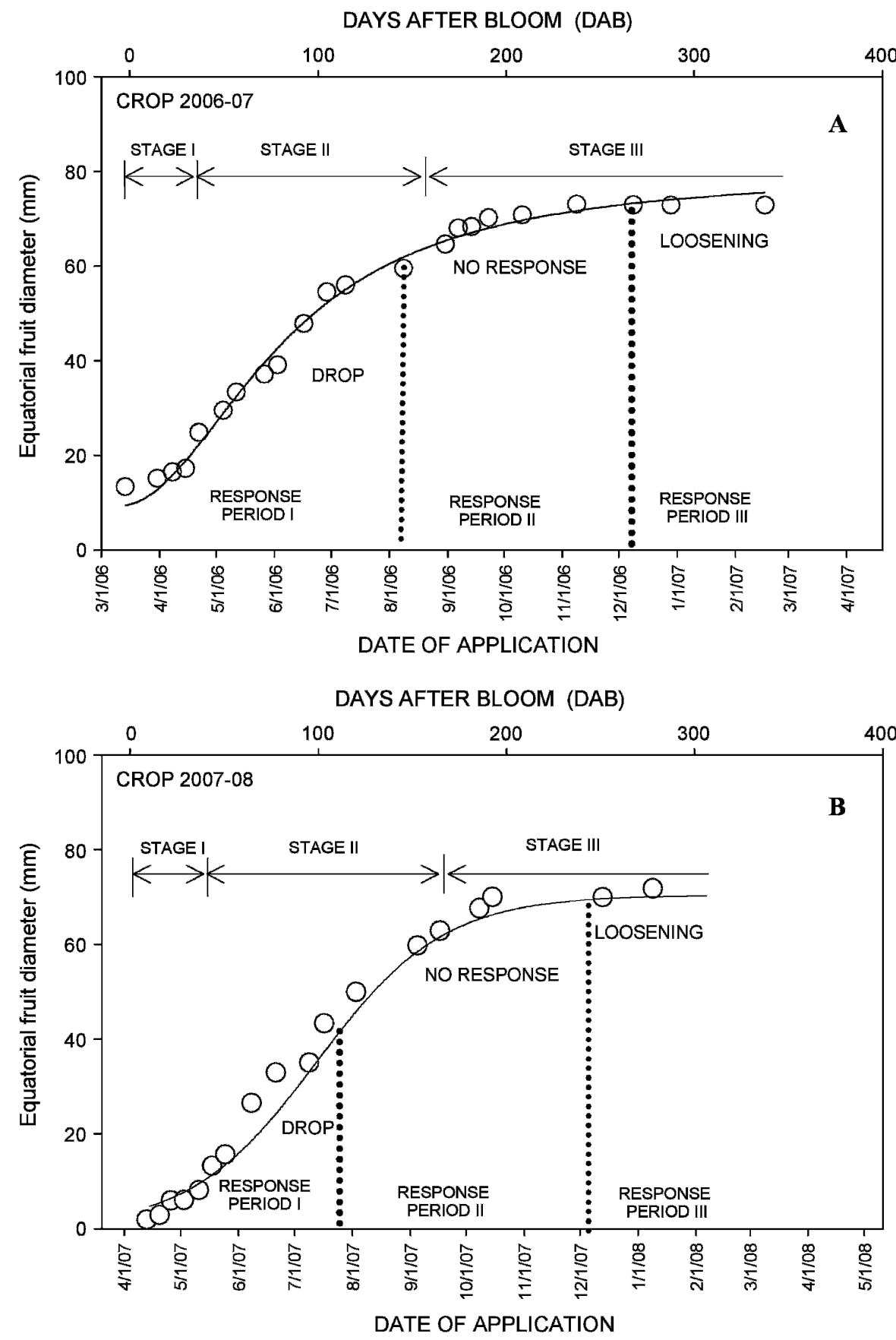

Fig. 3. Growth curves of 'Valencia' sweet orange fruit in 2006-2007 (A) and 2007-2008 (B) cropping years. Growth is expressed as equatorial diameter in millimeters at the dates indicated. Vertical dotted lines delineate fruit abscission responses and Response Periods. Growth curves were fit to sigmoidal third parameter equations: $\mathrm{A}, \mathrm{y}=68.43 /\left\{1+\mathrm{e}^{[(-(\mathrm{x}-83.85) / 32.29)]}\right\} ; \mathrm{B}, \mathrm{y}+70.4 /\left\{1+\mathrm{e}^{[(-(\mathrm{x}-88.7) / 30.0)]}\right\}$. Correlation coefficients and significance are $\mathbf{A}: \mathrm{R}=0.995, P<0.0001 ; \mathbf{B}: \mathrm{R}=0.99, P<0.0001$. Fruit growth and development stages described by Bain (1958) are located at the top of each graph. Abscission agent response periods are shown.

from 225 DAB to harvest, was characterized by a gain in sensitivity to abscission agents. In contrast to fruitlet response during Period I, significantly less mature fruit sprayed with CMNP were retained when compared with ethephon. Mature fruit sprayed with ethephon $+1-\mathrm{MCP}$ were retained on branches and did not drop. However, these fruit did loosen as indicated by a significant decrease in FDF measured in the 2007-2008 cropping year (Fig. 2). Other than ethephon $+1-\mathrm{MCP}$ treatment, trends in mature fruit retention (Fig. 1) and FDF (Fig. 2) were similar.

Changes in fruit diameter were plotted during both cropping years (Fig. 3). Three fruit growth development stages as defined by Bain (1958) were observed: cell division (Stage I; 0 to $50 \mathrm{DAB}$ ), cell elongation (Stage II; 50 to $200 \mathrm{DAB}$ ), and cell maturation (Stage III; beyond 200 DAB). Abscission agent Response Period I, characterized by high initial but decreasing sensitivity to 
abscission agent treatment, was associated with the cell division (Stage I) and most of the cell enlargement stage (Stage II). The transition from the cell enlargement to the cell maturation stage (beginning $\approx 100$ and ending $250 \mathrm{DAB}$ ) was characterized by little or no response to abscission agent application. As fruit and cell maturation continued, fruit again gained sensitivity to abscission agents.

No clear pattern in sensitivity of leaf abscission was observed during the two cropping cycles (Fig. 4A-B). Ethephon markedly increased leaf abscission, whereas CMNP or 1-MCP alone had little effect when compared with leaf loss from control branches. Ethephon-induced leaf abscission was significantly reduced by addition of 1MCP to ethephon sprays. However, leaf loss from ethephon + 1-MCP remained higher than that from CMNP, 1-MCP alone, or control treatments during most of the two cropping years. In 2006-2007, leaf loss resulting from ethephon treatment (Fig. 4A) appeared to follow the response pattern of fruit (Fig. 1A), whereas in 2007-2008, leaf abscission was high but variable throughout the cropping cycle (Fig. 4B).

Expt. 2: Leaf area index, yield, and return bloom in whole tree canopies sprayed with abscission agents. Leaf loss in whole canopies after abscission agent applications 6 and $28 \mathrm{DAB}$ in 2007 was similar to that of branch tests. Nearly $80 \%$ leaf drop occurred $30 \mathrm{~d}$ after ethephon application (data not shown). LAI was measured 7 months after application in Nov. 2007 to determine recovery of leaves and future impact on yield and return bloom. No effect of spray date on LAI within each spray treatment was observed ( $P \leq 0.05$; data not shown). Average LAI ranged from 4.1 to 4.6 . Despite high initial leaf loss in ethephon-treated trees, LAI was not statistically different from any other treatment.

No significant effect of application date on yield was measured within each spray treatment in Mar. 2008 ; $\approx 10$ to 11 months after application of abscission compounds. However, when compared with yield in 2007 , total mature fruit weight harvested from trees treated with ethephon was significantly less in 2008 when compared with other treatments (Fig. 5A). Fruit size measurements indicated that the diameter of ethephon-treated fruit was not significantly different from other treatments, including controls $(73 \mathrm{~mm}$ average diameter; $P \leq 0.05$; data not shown). Although CMNP or 1-MCP + ethephon application 6 and $28 \mathrm{DAB}$ resulted in $25 \%$ to $50 \%$ less fruitlets retained as indicated by our branch studies, yield was not significantly different from control trees. Moreover, 1-MCP application alone did not increase yield in 2008, indicating that minor improvements in fruitlet retention when applied 6 and $28 \mathrm{DAB}$ in 2007 did not result in more fruitlets developing into harvestable fruit in 2008. Return bloom in 2008 was counted 1 week after harvest on trees treated 6 and 28 DAB in 2007 with abscission compounds. Only ethephon treat-
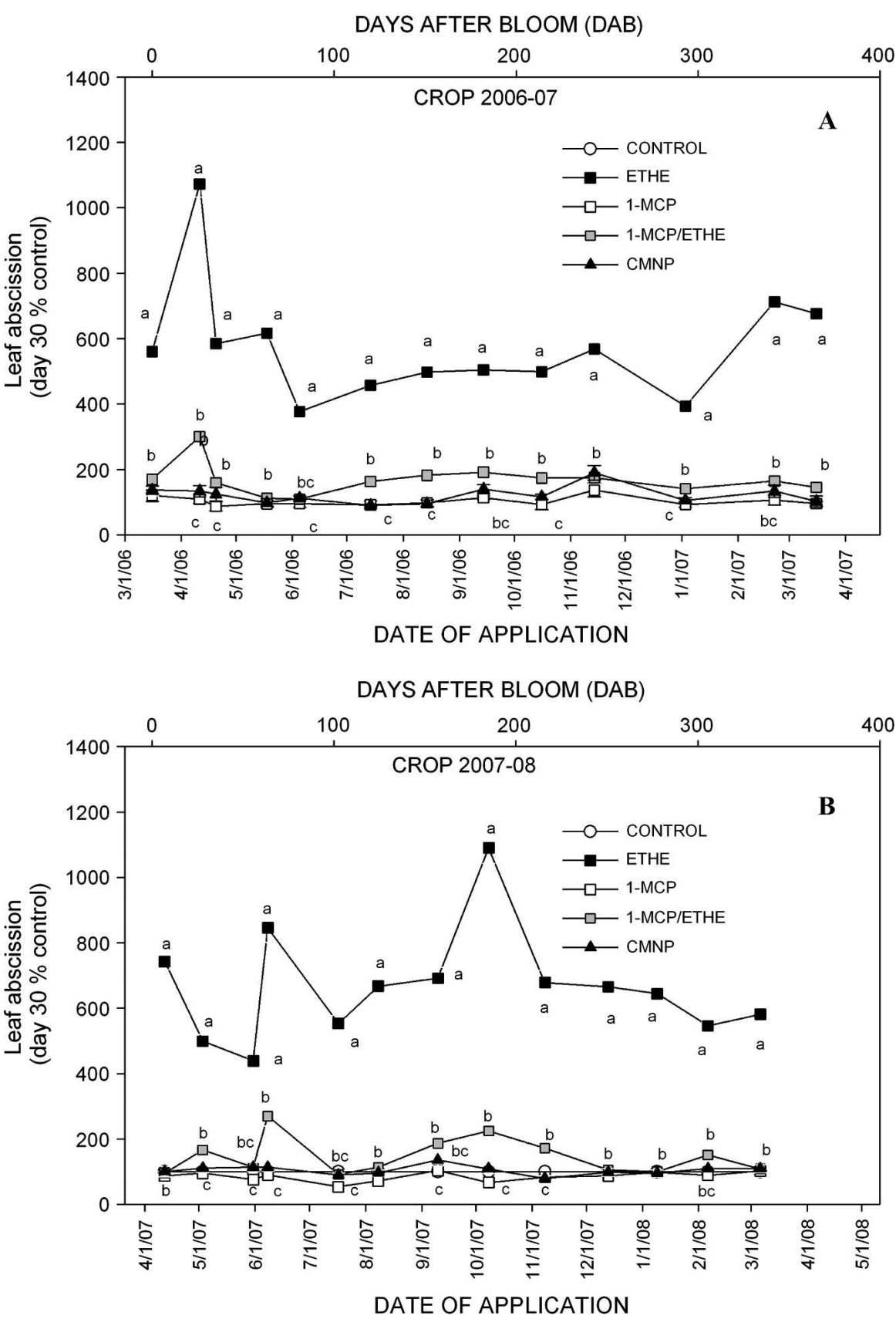

Fig. 4. Cumulative leaf abscission of 'Valencia' sweet orange as percent adjuvant control $30 \mathrm{~d}$ after application. Treatments were applied to runoff as branch sprays in two cropping years at the dates indicated: (A) 2006-2007; (B) 2007-2008. Means with the same letter within the same date of application are not significantly different as indicated by Duncan's multiple range test $(P \leq$ $0.05)$. Ethe $=$ ethephon; $1-\mathrm{MCP}=1$-methylcyclopropene; $\mathrm{CMNP}=5$-chloro-3-methyl-4-nitro- $1 \mathrm{H}$ pyrazole.

ment increased return bloom (Fig. 5B). The ethephon-treated trees had significantly greater numbers of bloom in 2008 when compared with all other treatments.

\section{Discussion}

Fruit were highly sensitive to ethephon applications during the cell division and cell expansion growth and developmental stages. In many fruit crops that exhibit alternate bearing or fruit size problems, ethylene-releasing or ethylene-promoting fruitthinning agents such as ethephon or NAA applied during this time improve final fruit size by adjusting crop load early in fruit development (Costa et al., 2006). Thinning practices are effective in overloaded trees (Guardiola and García-Luis, 2000) when young fruitlet removal reaches $\approx 50 \%$ (Agustí et al., 1995, 2002; Zaragoza et al., 1992). However, efficacy of thinning agents is highly variable, and application timing is critical for success.

As citrus fruitlets developed after bloom, sensitivity to ethephon was high and variable from year to year but decreased as growth continued. Ethephon concentrations up to 

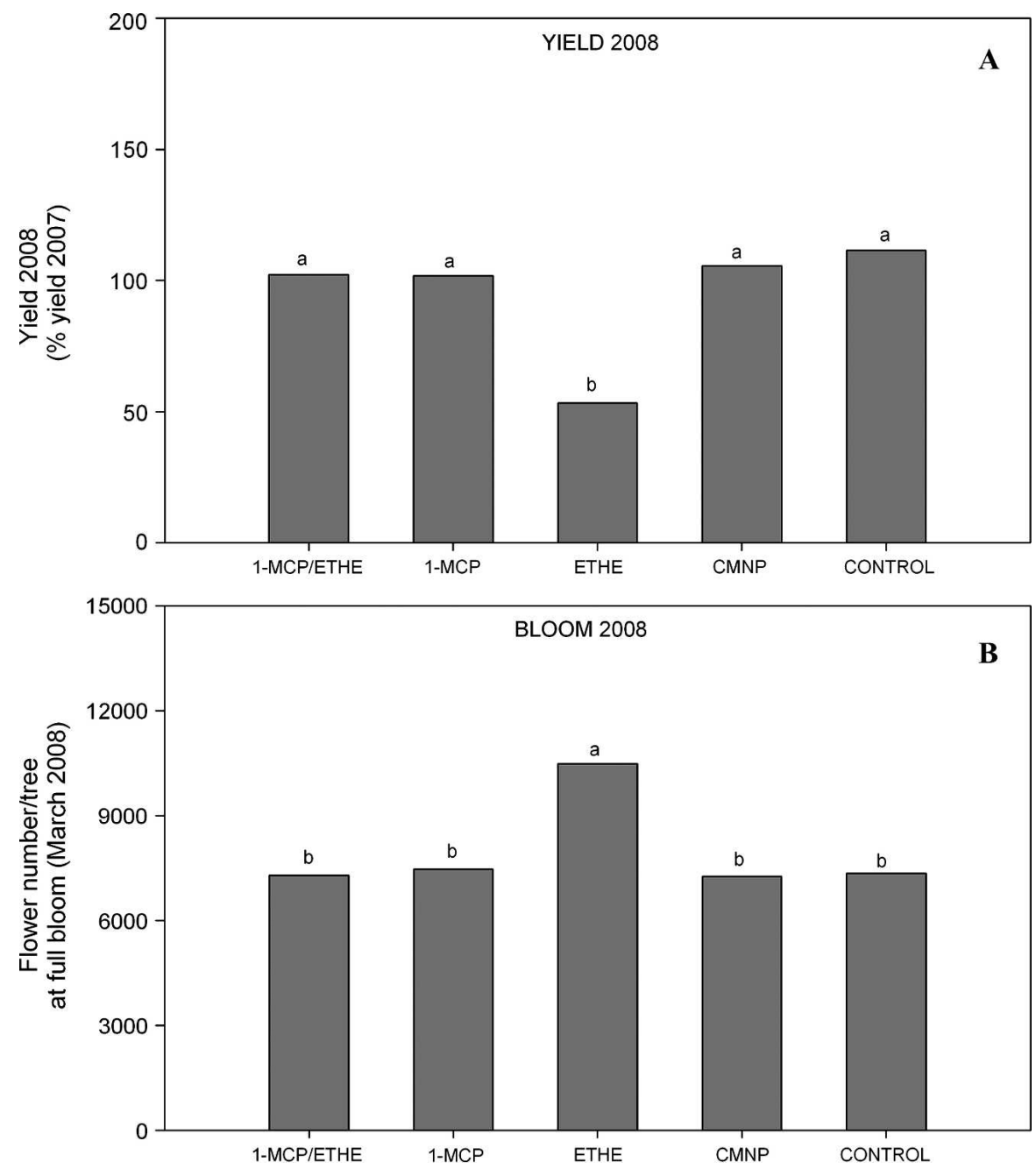

Fig. 5. Comparative yield in 2008 expressed as percent 2007 yield (A) and total canopy flower number at full bloom in Mar. 2008 (B) in 'Valencia' sweet orange. Trees were sprayed in Mar. 2007 at 6 and $28 \mathrm{~d}$ after bloom. Since there was no significant effect of application date, data were pooled and the means graphed for each spray treatment. Means of yield or flower number with the same letter are not significantly different as indicated by Duncan's multiple range test $(P \leq 0.05)$.

$400 \mathrm{mg} \cdot \mathrm{L}^{-1}$ applied during Response Period I reduced fruit number in "on-crop" years, but unpredictable fruitlet removal and intense defoliation prevented its wide-scale use as a thinning agent in citrus-growing areas where thinning is needed (Gallash, 1974; Hutton, 1992; Kender et al., 2000). Young citrus fruitlets behave as climacteric fruit with System II-like autocatalytic ethylene biosynthesis activity (Katz et al., 2004). System II gives way to System I as development proceeds, which is characterized by low internal ethylene production and autoinhibition. Together with the balance between phytohormones such as auxin (Gómez-Cadenas et al., 2000; Goren, 1993; Talon et al., 1992), this System I to System II transition in part explains high sensitivity to ethylenereleasing agents in fruitlets and reduction in sensitivity as fruitlets continue to develop (Oetiker and Yang, 1995). Developmental and physical constraints may also contribute to altering abscission sensitivity as fruitlets develop from Response Periods I to II. During the first 8 weeks of fruit development, abscission occurs through the pedicel abscis- fruit maturation progresses (Costa et al., 2006; Yuan et al., 2001). CMNP may alter the phytohormone balance in favor of accelerated abscission, or alternatively, fruit could be more developmentally sensitive to CMNP as maturation proceeds. Whatever mechanism, CMNP causes rapid and predictable citrus mature fruit abscission under environmental conditions common to Florida (Burns, 2002).

As a result of high fruitlet loss, significant yield reduction in 2008 after ethephon application around bloom time in 2007 is not surprising. The population of ethephonabscised fruitlets is likely composed of those weakening organs that would naturally drop to adjust fruit load and those that would normally advance to maturity. CMNP is a better choice for loosening mature fruit for mechanical harvest during this highly sensitive fruitlet removal phase. Subsequent yield is not impacted, although up to $50 \%$ fruitlet loss may occur. This amount of fruitlet loss may be close to a threshold compensation point beyond which yield reductions occur. The mode of action of CMNP is not yet known, but uncoupling activity and marked ethylene production were associated with its application in mature fruit (Alferez et al., 2005; Yuan and Burns, 2004). Nothing is known about CMNP-induced ethylene production in Response Periods I and II fruitlets. Significant detoxification reactions postulated to occur in leaves and fruitlets (Li et al., 2008) may minimize the ability of CMNP to induce abscission in these organs.

Unpredictable defoliation is a major drawback of ethephon when used alone as a mature fruit abscission agent for mechanical harvesting, especially during the critical cell division stage. In previous work, manual defoliation between $25 \%$ to $50 \%$ of leaves during 2 consecutive years within this highly responsive cell division stage adversely impacted yield (Yuan et al., 2005). High levels of ethephon-induced defoliation, together with loss of fruitlets, probably contributed to yield loss, although LAI recovered later. The fact that CMNP application did not reduce yield indicates that fruitlet loss did not reach the critical level required to reduce yield. The use of the ethylene perception inhibitor 1-MCP combined with ethephon application during Response Period I alleviated ethephon-induced fruitlet loss and defoliation with no impact on final yield. The fact that mature fruit loosening still occurred with minimal drop of fruit, fruitlets, and leaves gives a new outlook for ethephon with 1MCP as a potential practical abscission agent for Florida citrus (Burns, 2008; Pozo et al., 2004).

Reduction of yield resulting from ethephon application was followed by a significant increase in subsequent flower number. A plausible explanation could be an accumulation of leaf carbohydrates after reduction in total fruit sink strength leading to increased flowering and fruit retention the next year (Goldschmidt, 1999; Iglesias et al., 2002). Such 
a scenario could increase nutrient availability for subsequent bloom as well as lower total gibberellin content (Garcia-Luis et al., 1986; Guardiola et al., 1982), resulting in effective regulation of the flower induction period (Erner, 1989; Koshita et al., 1999; Monselise, 1985). A follow-up count of developing fruit and their diameters 5 months after bloom indicated no significant difference in number or size between treatments (data not shown), but final 2009 yield measurements are needed to verify this outcome.

In summary, there were three fruit response periods after application of abscission agents. Response Period I occurred within the first 100 DAB and was characterized by initially high but decreasing sensitivity to abscission agents, most notably ethephon. Response Period II, characterized by little or no response to abscission agents, occurred between $\approx 100$ and 250 DAB. Response Period III occurred $250 \mathrm{DAB}$ and beyond and was characterized by a gain in sensitivity to abscission agents, especially CMNP. A combination of high fruitlet loss and defoliation resulting from ethephon application early in Response Period I resulted in significant reduction in subsequent yield. Combining ethephon with 1-MCP application alleviated unwanted fruitlet loss and defoliation and improved final yield.

\section{Literature Cited}

Abeles, F.B., P. Morgan, and M.E. Saitveit. 1992. Ethylene in plant biology. Academic Press, San Diego, CA.

Agustí, M., M. El-Otmani, M. Aznar, M. Juan, and V. Almela. 1995. Effect of 3,5,6-trichloro-2pyridyloxyacetic acid on clementine early fruitlet development and on fruit size at maturity. J. Hort. Sci. 70:955-962.

Agustí, M., S. Zaragoza, D.J. Iglesias, V. Almela, E. Primo-Millo, and M. Talón. 2002. The synthetic auxin 3,5,6-TPA stimulates carbohydrate accumulation and growth in citrus fruit. Plant Growth Regulat. 36:141-147.

Alferez, F., S. Singh, A.L. Umbach, B. Hockema, and J.K. Burns. 2005. Citrus abscission and Arabidopsis plant decline in response to 5-chloro-3-methyl-4-nitro-1H-pyrazole are mediated by lipid signaling. Plant Cell Environ. 28:1436-1449.

Bain, J.M. 1958. Morphological, anatomical and physiological changes in developing fruits of 'Valencia' orange, Citrus sinensis. Aust. J. Bot. 6:1-24.

Brown, K.M. 1997. Ethylene and abscission. Physiol. Plant. 100:567-576.

Bukovac, M.J., F. Zucconi, R.P. Larsen, and C.D. Kesner. 1969. Chemical promotion of fruit abscission in cherries and plums with special reference to 2-chloroethylphosphonic acid. J. Amer. Soc. Hort. Sci. 94:226230.

Burns, J.K. 2002. Using molecular biology tools to identify abscission materials for citrus. HortScience 37:459-464.
Burns, J.K. 2008. 1-Methylcyclopropene applications in preharvest systems: Focus on citrus. HortScience 43:112-114.

Burns, J.K., R.S. Buker, and F.M. Roka. 2005. Mechanical harvesting capacity in sweet orange is increased with an abscission agent. HortTechnology 15:758-765.

Burns, J.K., L.V. Pozo, C.R. Arias, and B. Hockema. 2003. Coronatine and abscission in citrus. J. Amer. Soc. Hort. Sci. 128:309-315.

Burns, J.K., F.M. Roka, K.-T. Li, L. Pozo, and R.S. Buker. 2006. Late season 'Valencia' orange mechanical harvesting with an abscission agent and low frequency harvesting. HortScience 41:660-663.

Costa, G., V. Dal Cin, and A. Ramina. 2006. Physiological, molecular and practical aspects of fruit abscission. In: Webset, A.D. and H. Ramirez (eds.). Proc. Xth IS on Plant Bioregulators in Fruit. Acta Hort. 727. ISHS.

Erner, Y. 1989. Citrus fruit set: Carbohydrate, hormone and leaf mineral relationships, $\mathrm{p}$. 233-242. In: Wright, C.J. (ed.). Manipulation of fruiting. Butterworth-Heinemann, Boston, UK.

Gallash, P.T. 1974. Regulating Valencia orange crops with CEPA (2-chloroethyl phosphonic acid)-Preliminary studies. Aust. J. Expt. Agr. Anim. Husb. 14:835-838.

Garcia-Luis, A., V. Almela, C. Monerri, M. Agustí, and J.L. Guardiola. 1986. Inhibition of flowering in vivo by existing fruits and applied growth regulators in Citrus unshiu. Physiol. Plant. 66:515-520.

Goldschmidt, E.E. 1999. Carbohydrate supply as a critical factor for citrus fruit development and productivity. HortScience 34:1020-1024.

Gómez-Cadenas, A., J. Mehouachi, F. Tadeo, E. Primo-Millo, and M. Talón. 2000. Hormonal regulation of fruitlet abscission induced by carbohydrate shortage in citrus. Planta 210:636-643.

Goren, R. 1981. Regulating the abscission process in citrus by growth substances. Acta Hort. 120:59-69.

Goren, R. 1993. Anatomical, physiological and hormonal aspects of abscission in citrus. Hort. Rev. (Amer. Soc. Hort. Sci.) 15:33-46.

Goren, R. and M. Huberman. 1976. Effects of ethylene and 2,4-D on the activity of cellulose isoenzymes in abscission zones of the developing orange fruit. Physiol. Plant. 37:123-130.

Greenberg, J., R. Goren, and J. Riov. 1975. The role of cellulose and polygalacturonase in abscission of young and mature Shamouti orange fruits. Physiol. Plant. 34:1-7.

Guardiola, J.L. and A. García-Luis. 2000. Increasing fruit size in citrus. Thinning and stimulation of fruit growth. Plant Growth Regulat. 31:121132.

Guardiola, J.L., C. Monerri, and M. Agusti. 1982. The inhibitory effect of gibberellic acid on flowering in citrus. Physiol. Plant. 5:136-142.

Hartmond, U., R. Yuan, J.K. Burns, A. Grant, and W.J. Kender. 2000. Citrus fruit abscission induced by methyl-jasmonate. J. Amer. Soc. Hort. Sci. 125:547-552.

Huberman, M., R. Goren, and E. Zamsk. 1983. Anatomical aspects of hormonal regulation of abscission in citrus-The shoot-peduncle abscission zone in the non-abscising stage. Physiol. Plant. 59:445-454.
Hutton, R.J. 1992. Improving fruit size and packout of late Valencia oranges with ethephon fruitthinning sprays. Aust. J. Expt. Agr. 32:753-758.

Iglesias, D.J., I. Lliso, F.R. Tadeo, and M. Talón. 2002. Regulation of photosynthesis through source:link imbalance in citrus is mediated by carbohydrate content in leaves. Physiol. Plant. 116:563-569.

Katz, E., P. Martínez, J. Riov, D. Weiss, and E. Goldschmidt. 2004. Molecular and physiological evidence suggests the existence of a system II-like pathway of ethylene production in nonclimacteric citrus fruit. Planta 219:243-252.

Kender, W.J., U. Hartmond, R. Yuan, L. Pozo, and A. Grant. 2000. Factors influencing the effectiveness of ethephon as a citrus fruit abscission agent. Proc. Fla. State Hort. Soc. 113:88-92.

Koshita, Y., T. Takahara, T. Ogata, and A. Goto. 1999. Involvement of endogenous plant hormones (IAA, ABA, gas) in leaves and flower bud formation of satsuma mandarin (Citrus unshiu Marc). Sci. Hort. 79:185-194.

Li, K.-T., J.K. Burns, and J.P. Syvertsen. 2008. Recovery from phytotoxicity after foliar application of fruit loosening abscission compounds to citrus. J. Amer. Soc. Hort. Sci. 133:535-541.

Monselise, S.P. 1985. Citrus and related species, p. 275-294. In: Halevy, A.H. (ed.). Handbook of flowering. Vol. II. CRC Press, Boca Raton, FL.

Oetiker, J.H. and S.F. Yang. 1995. The role of ethylene in fruit ripening. Acta Hort. 398:167178.

Pozo, L. and J.K. Burns. 2000. Ethylene action inhibitors reduced Ethrel-induced leaf drop and gummosis in citrus. Proc. Int. Soc. Citricult. IX Congr. p. 578-579.

Pozo, L.V., R. Yuan, I. Kostenyuk, F. Alferez, Y. Zhon, and J.K. Burns. 2004. Differential effects of 1-methylcyclopropene on citrus leaf and mature fruit abscission. J. Amer. Soc. Hort. Sci. 129:473-478.

Talon, M., L. Zacarias, and E. Primo-Millo. 1992. Hormonal changes associated with fruit set and development in mandarins differing in their parthenocarpic ability. Physiol. Plant. 79:400406.

Yuan, R., F. Alférez, I. Kostenyuk, S. Sing, J. Syvertsen, and J.K. Burns. 2005. Partial defoliation can decrease average leaf size but has little effect on orange tree growth, fruit yield and juice quality. HortScience 40:20112015.

Yuan, R. and J.K. Burns. 2004. Temperature factor affecting the abscission response of mature fruit and leaves to CMN-Pyrazole and ethephon in 'Hamlin' oranges. J. Amer. Soc. Hort. Sci. 129:287-293.

Yuan, R., U. Hartmond, and W.J. Kender. 2001. Physiological factors affecting response of mature 'Valencia' oranges to CMN-pyrazole. II. Endogenous concentrations of indole-3acetic acid, abscisic acid and ethylene. J. Amer. Soc. Hort. Sci. 126:420-426.

Zaragoza, S., I. Trenor, E. Alonso, E. PrimoMillo, and M. Agustí. 1992. Treatments to increase the final fruit size on Satsuma Clauselina. Proc. Int. Soc. Citricult. 2:725728. 